\title{
Legitimization and Validity of Directives on Legal Interpretation on the Example of the Rule of Law Crisis in Poland
}

\section{Robert Piszko ${ }^{1}$ [D}

Accepted: 5 October 2020 / Published online: 14 October 2020

(c) The Author(s) 2020

\begin{abstract}
In case when the criteria for the validity of interpretative directives are not clearly defined and a political dispute arises, the dispute participant may refer to such interpretative directives, the use of which will determine the content of the law and determine the outcome of the political dispute. In this way a crisis of the legal order in Poland has occurred. Therefore, the aim of this article is to draw attention to the consequences of the undefined status of the directives of legal interpretation, the resulting need for legitimacy of the interpretation of the law, the role of legal views (legal doctrine) possible in this respect and the validation role of the interpretation custom in legal doctrine. The article consists of four parts. The first one describes the phenomena that have disrupted the traditional approach to the sources of law. The second part describes the traditional approach to the sources of the law. The third one proves that the traditional approach to the sources of law, in which the main role is fulfilled by normative acts, is incorrect, this part also indicates that the key role in this respect is played by spontaneous rules of law interpretation. The fourth part indicates the need to legitimize the interpretation of the law and the role of the interpretation custom in judicial doctrine. The research material includes parliamentary practice in Poland, practice of law interpretation and scientific studies on law interpretation. The research material was examined mainly using the method of linguistic analysis.
\end{abstract}

Keywords Legitimization - Legal interpretation · Sources of law · Legal system crisis $\cdot$ Rule of law $\cdot$ Custom

Robert Piszko

piszko@inet.pl

1 University of Szczecin, Al. Jana Pawła II nr 22, Szczecin, Poland 


\section{Introduction}

In 1989, political changes were initiated in Poland in a rational and seemingly unquestionable way. For many years, the Polish legal system ${ }^{1}$ seemed exemplary, in a sense, not only in the context of former Eastern Bloc countries but also as a general measure. It seemed that nothing would interfere with the development of the state and the law, economic development, and respect for civil rights and freedoms. It also seemed that the development of Polish society would be inclusive and that Poland would be free from social unrest. Therefore, the international community was greatly surprised by the dispute among the Constitutional Tribunal, the Supreme Court, and the common courts, which has been going on for several years, starting in 2016, and which, at the time of this article's drafting, still has not been concluded. This is a dispute in which different attitudes towards the Polish Constitution's provisions and the Polish legal system have emerged, including attitudes that undermine the foundations of Poland's legal order. In fact, the coherence and even the very existence of the concept of sources of law was questioned; the latter was questioned mainly as it pertains to the part that is not included in the Constitution of the Republic of Poland while the former was questioned with regard to the part that is not covered by the subject of legal science. It is also worth noting that similar phenomena were previously present in judicial legal practice.

Subject to variances in methodological approach, the dispute in questioned to a political crisis of the state and the law in Poland, specifically crises in the Polish legal system, law science, and democracy [16: 96-98]. ${ }^{2}$ These phenomena are directly connected with events related to those surrounding the Constitutional Tribunal, the Supreme Court, and the common courts. It would be interesting to learn about the causes of this crisis and the tendency to take a certain attitude towards the legal system, and as such, these are the inquiries that this article addresses. There are certainly many possible causes of such a crisis in the Polish legal system. It can be argued, for instance, that the ,crisis of Poland" is structurally inscribed in the demolition of liberalism since the handing over of power to expert bodies caused a kind of ,politicisation" of the relevant bodies' decisions because they started making political decisions instead of legal or juridical decisions. These decisions should be incidental and temporary as opposed to the ones producing effects „forever”. Although the author does not question the potentiality of such reasons, to which one could also add economic reasons, the subject of this article will be to determine whether the causes of the crisis in Poland are of a structural nature, and therefore, whether they are related to the construction of the legal system in Poland. As evidenced by

\footnotetext{
1 „Legal system” may have several meanings, two of which are frequently referred to by the theoretical sciences of jurisprudence. The first one, to which this article will not refer, is connected with the meaning of the term ,system of legal norms". The second one, to which this article does refer, combines „legal system” with „legal order”. In this article, the author uses ,legal order” to mean a legally regulated state of social, political, and economic orderliness in a given state.

2 The article addresses the crisis on concerns all these levels of the crisis. If the causes or circumstances are proven common to all of these phenomena, the terms ,crisis of the state and the law in Poland” or: „Polish crisis” will be used.
} 
the dispute, readiness to adopt different attitudes towards 'what is law and what is not' clearly indicates the need to consider the construction of the legal system within the scope of sources of law. The fact that such attitudes are presented without legal regulations or on the basis of their different interpretations draws attention to the socalled ,non-legal sources of law”.

Regardless of how convinced the author may be about the reasons for the crisis in the Polish legal system, the hypotheses presented in this article will be justified by the author's assessment of the situation of the state and the law in Poland.

In summary, the author was inspired to write this article by the crisis in the field of sources of law, in particular of the so-called ,unwritten sources of law" and the problem of their validity in the Polish legal system, and thus, in particular, the problem of legitimacy of legal interpretation. However, it is not about the legitimization of the law, ${ }^{3}$ but about the legitimization of the interpretation of the law, and more specifically - about the legitimization of directives on legal interpretation ${ }^{4}$ in a specific legal order. ${ }^{5}$ According to the author, the crisis of the rule of law in the EU is also related not only to the rule of law [22: 561-576], but also to the issue of legitimacy of law interpretation.

According to the author, the legitimacy of the interpretation of the law is a problem corresponding to the issue of the ,source of law" argument. The source of law argument is considered as justifying the action, showing that its legal basis is the best interpretation of a rule, principle or value identified in the material source of law. ,Such an argument is authority-based in that it appeals for its correctness to a collective decision to adopt a particular rule." [2: 40-71]. This means that the problem of sources of law described in this article is also universal. The article does not contain polemics in the views of other authors. It is intended to (among other things) support them.

\section{Research Perspective: The Aim of the Study}

In 2016, several appeals (e.g. no. 1709 [11], 3193 [12] were submitted to the Seym (Polish parliament) concerning the publication of judgments of the Constitutional Tribunal. According to the interpellating Member of Parliament, in compliance with Article 190 of the Constitution of the Republic of Poland (Sect. 2), the judgments of the Constitutional Tribunal in the cases listed in Article 188 are immediately announced in the official journal of the legal acts of the Republic of Poland in which the normative act was announced. The appeal also pointed out that the obligation to publish the rulings of the Constitutional Tribunal results likewise from Article 9 Sect. 1 point 6 of the Act on promulgation of normative acts and certain

\footnotetext{
${ }^{3}$ Legitimisation is a justification, validation or justification of validity (justified simplification).

4 A directive on legal interpretation is a technical directive, i.e. an expression indicating how to achieve a certain objective. It can be attributed to any interpretation procedure. It sets out the procedure.

5 The legal order, in this article, is the legal order of social, political and economic relations in a particular country.
} 
other legal acts. Pursuant to Article 2 of the same Act, the announcement of a normative act in the official journal is obligatory, while Article 3 orders its publication immediately, i.e. without undue delay. Thus, the announcement of the rulings of the Constitutional Tribunal is a constitutional obligation and is subject to immediate execution by the authority obliged to do so, which is the Prime Minister. The Polish Constitution does not provide for any exception in this respect. The decision of the Constitutional Tribunal must be published, because in accordance with Article 190, paragraph 3 of the Constitution, such decision enters into force on the day of its announcement.

In response, the ruling party stated that in accordance with Article 21 Sect. 1 of the Act of 20 July 2000 on promulgation of normative acts and certain other legal acts (Dz.U. 2015, item 1484, as amended), the Prime Minister issues the Official Journal of the legal acts of the Republic of Poland. This is an independent competence of the Prime Minister and therefore, as one can guess, the Council of Ministers does not have to publish the decision of the Constitutional Tribunal [13].

The interlocutor has not indicated why she believes that the expression: ,,are subject to immediate publication", is tantamount to articulating the obligation to publish, nor did she indicate why the provision of Article 2 Sect. 1 of the Act on the promulgation of normative acts and certain other legal acts of wording: „Announcement of a normative act in the official journal is mandatory" also applies to decisions of the Constitutional Tribunal.

In the first case, the position of the interpellating Member of Parliament would be justified by a directive of interpretation of the law in its wording: ,the use of the verb in the third person singular or in the third person plural form, in the indicative mode and present tense, in a legal provision, determines the dispatch of the obligation to proceed".

In the second case, there would be necessary a directive according to which each time the normative acts are mentioned in the wording of the Act on promulgation of normative acts and certain other legal acts the provisions also refer to the judgments of the Constitutional Tribunal.

However, the position of the government party would be justified by the directive, according to which the phrase, immediately announced" contained in the provisions of the law does not give rise to an obligation for the Prime Minister who is competent to announce a normative act to do so.

In both cases, a question should be asked as to the basis for the validity or justification of the choice of the directives in question. However, the question does not concern the content of the law (each of the sides presented sees its content differently), but it concerns the way in which the content of the law is determined. Therefore the point is not the legitimacy of the law, but the legitimacy of the interpretation of the law, and more specifically the legitimacy of the interpretation of the law directives in a particular legal order. 


\section{Research Problem}

In the above-mentioned actual situation, it is a matter of deciding which of the directives of legal interpretation is in force or should be chosen for other reasons, which is connected with the problem of legitimacy of the legal interpretation and not with the problem of legitimacy of the law [17: 363,364]. Therefore, the author's aim is to consider the necessity of legitimacy of directives of legal interpretation and the way in which legitimacy could be implemented. Phenomena that have disavowed the traditional approach to the sources of law have determined the necessity of legitimizing the interpretation of law. This draws attention to the role of judicial views, i.e. judicial doctrine in the practice of legal interpretation. The need to consider the manner in which the legitimization of the interpretation of the law could be realized indicates a possible validation role of the interpretation custom in the legal doctrine. Therefore, the article describes at the beginning the consequences of the undefined status of legal interpretation directives [1-3]. Then it defines the traditional approach to the sources of the law $[4,5]$. It then argues that the traditional approach to the sources of law, in which normative acts have a major role to play, is incorrect [6, 7] and indicates that the key part is played by spontaneous rules of law interpretation, which determines the need for legitimacy of law interpretation [8-10]. Finally, it discusses the role of legal doctrine and custom as a form of legitimacy of the interpretation of the law, which includes the validation role of judicial views. The parliamentary practice in Poland in the years 2015-2020, as well as the politically conditioned practice of law interpretation turned out to be extremely valuable as a subject of research. Scientific studies on legal interpretation were less useful. The research material was examined using the method of analysis, including linguistic analysis [25: 97-126,129-137] and the theory of rational choice in law [21], [27:790-818].

\section{Sources of Law}

Statements on the subject show that sources of law are discussed either in a normative, dogmatic manner (established norms should be complied with as are the binding norms established for a given legal system) or as descriptive and theoretical (specific facts are considered law-making and the persons on whom these depend are ready to adequately respond to the relevant norms). Sources of law can even include any phenomena that may impact the „,content” of the law.

Acting within a certain institutional framework, the state is the main but not the only ,lawmaker". The state's law-making may be associated with normative analysis that is focused on the competence, process, and results of law-making. It may also include other issues such as the forms and rationality of law-making, the principles of normative drafting, law policy, models, and transparency.

Society can also play a role in law-making. At the end of the twentieth century, the role of the state in the law-making process was significantly limited by various social integration and disintegration processes. In this respect, analyses may concern various sociological, theoretical, and philosophical approaches that underscore the 
more or less ,statist” character of law, thus emphasising its economic, social, political, and international conditions.

Culture seems to determine the ultimate horizon for thinking about the processes of shaping and creating law, thus constituting a material source of law. In this dimension, value systems, ideas, principles, and common historical experiences deserve special attention. They are treated as universal output; for example, human dignity, natural law, human rights (or specific human rights) may be considered the cultural output of a given society, nation, or smaller social group.

\section{The Normative Concept of Sources of Law: the Literature}

This article's starting point consists of the concept of sources of law that is expressed in legal regulations (the Constitution of the Republic of Poland) and the components that are theoretically necessary to determine which norm is binding in the context of the legal system. These components are: regulatory competences, custom, precedent, the axiological basis of the legal order, interpretative directives, inference directives, and the conflict of laws rules that allow for the resolution of norm-related conflicts in the legal system [33: 79-105, 34:244-311]. ${ }^{6}$

Interpretative and inference directives have a rich literature, but conflict of laws directives have been addressed much less frequently. The status of all these directives has rarely been discussed, thus neglecting the problem of their validity. However, the axiological foundations of the legal system have been discussed many times, albeit in a manner that only covers certain aspects. ${ }^{7}$ Theoretical and legal literature on ,spontaneous" sources of law and their role in the creation of law practically exclusively relate to the author of this article.

The problem of sources of law can be considered using the following typologies: normative and non-normative, written and unwritten, and formal and informal. However, given that this is not the subject of this work, we will simply note that the spontaneous formation of law is associated with non-normative, unwritten, or informal sources of law. We will now move on to examining the spontaneous formation of law and its role in the legal system.

\section{The Subject of Spontaneous Law-Making}

Within the framework of a slightly simplified analysis of sources of law, ${ }^{8}$ it can be assumed that given the current state of Poland's legal culture, the regulation of specific social relations and the social order are determined by a normative system in

\footnotetext{
${ }^{6}$ In Polish science, the first work that discusses elements of the normative concept of sources of law as defined in this paper is Z. Ziembińskis textbook Theory of Law [33].

7 The paper will omit evidence pertaining to the frequency of dealing with specific issues due to the scarcity of space and its relatively low relevance to the subject of concern.

8 So far, this has not happened in the science and practice of law.
} 
which information is provided to addressees. This information is usually provided in writing, most often in the form of legal regulations that are contained in a normative act. Legal regulations require that their recipient read and understand in order to determine which norm (rule) applies to a particular legal system. The content of the law is created as a result of this type of reasoning, which leads from specific premises to specific conclusions. Conclusions will vary according to which premises are taken into account, assuming that no premises were overlooked or undiscoverable. Even if we assume that the recipient is a lawyer, he/she will have personal characteristics (premises) that will exclude a standard reading of information about the law from possibility.

In this respect, Polish legal science offers sophisticated interpretations of concepts of law, including normative concepts. In the author's opinion, the concept of interpretation in Polish legal science is a set of statements concerning which principles, rules, and guidelines are or should be applied while interpreting the law. A normative legal interpretation concept formulates recommendations for action. These concepts are strictly theoretical in a manner similar to models that are proposed to the dogma of law and legal practice [3, 4, 20:107-193, 35]. They are also extremely complex constructions that differ from each other in terms of assumed epistemology, their relation to legal practice in the sense of the scope of the interpretative behaviours that are taken into account in legal practice (the relationship between the theory of interpretation and interpretative doctrine), and the construction of the theory of interpretation, which is usually a consequence of methodological assumptions that fall within a specific type of jurisprudence [36: 155-169, 10, 23]. Orientation within the scope of the concept of interpretation is exclusive; that is, not all lawyers are involved. This also applies to the so-called normative concepts of interpreting the law, which, in a sense, release the lawyer from epistemological or ontological considerations. From the point of view of legal practice, these are private sets of statements, rules, or guidelines for the interpretation (and application) of the law; therefore, in this respect, they share the fate of legal doctrine. The concepts of interpretation are not binding; their utilisation is at the disposal of the recipient, which means that a recipient can use several concepts, often without realising that they are based on different concepts' contradictory findings.

Even in the case of a model recipient, assuming, for example, that he or she is a lawyer who knows the theoretical issues inherent in interpreting the law, personal features (premises) will preclude a standard (common for all) reading. When reading information about the law, individual recipients will be inclined to prefer different rules (that is, they will participate in legal culture in different ways). For instance, recipients may be inclined to read information in a manner that corresponds to their current, broadly understood businesses. Such a reading is possible because legal regulations do not formalise the rules for reading information about the law. This is due, in part, to the possibility (and concomitant fear) of imposing excessive restrictions on necessary freedoms in this respect. In legal culture, such rules are not considered binding and the issue of their validity is not considered; rather, a choice between theoretically necessary elements of the concept of interpretation is substituted. 
In the „composition of the law”, one can see that there are substantive norms (essential part) and instrumental norms, which are a component of the usefulness of law (instrumental part). ${ }^{9}$

As H. L. Hart saw it, it seems that in the Polish legal system, what is necessary for the functioning of law is adopted (accepted) by the legal system's participants [31:56-57] This is contradicted, at least in part, by the events of the period 2016 to 2019; hence, there is a need to consider whether and, if so, how an instrumental part may be included in the legal system and what comprises it. ${ }^{10}$ It may be about various phenomena, states of affairs, or other creations; but there will certainly be rules and guidelines for the interpretation of legal phenomena and the application of law. Such principles, rules, and guidelines may practically become law albeit via a different method than through disclosure in the content of a legal provision, i.e., in a spontaneous manner. With some exceptions [14:193-200], sources of law are not noticeable in legal science, meaning that the principles, rules, and guidelines for the interpretation of legal phenomena and the application of the law are not discussed.

In fact, in juridical practice, the source of law has an impact on content and ,application". ${ }^{11}$ However, this is done in a way that is both unconscious and uncontrolled. These characteristics are revealed in different ways; most often, this depends on the competences or expectations of the person who ,applies",12 the law. It is not yet possible to comprehensively define the subject of the law; that would require a separate article. Traditionally, the content of the law is determined by normative competences since it is their use that enables us to obtain legal texts from which legal norms may originate. Custom and precedent are similar phenomena (known to the science of law) that may result in the creation of law. Both of these may complement the composition of the legal system's norms. Usually, legal texts that are created as a result of the use of normative rights do not take the formation of law by custom or precedent into account. Both legal texts and the content of norms that are created by custom and precedent need to be clarified. Gaining knowledge about their content requires considering directives on the interpretation of legal phenomena and the application of the law, which must somehow be included in the composition of legal norms since these are part of the law regardless of recipients' awareness. ${ }^{13}$

The well-established way of viewing the composition of the law includes ${ }^{14}$ substantive norms (essential part) and a legal utility component (instrumental part). Substantive standards may be included in the law either through their inclusion in the provisions of the law or spontaneously. Principles, rules, and guidelines for the interpretation of legal phenomena and the application of the law in all legal systems

\footnotetext{
9 Regarding the introduction of terms, substantive and instrumental norms do not constitute a typology. These are to be used only in the process of explaining the role of the spontaneous creation of law.

${ }^{10}$ However, this is a topic for a separate study.

11 This is about the interpretation and application of law.

12 The Interpretation of legal phenomena and the application of the law.

13 A separate paper is required to adequately demonstrate whether and, if so, how directives on the interpretation of legal phenomena and the application of the law are part of the legal system; however, given that the statement seems very probable, this paper adopts it as an assumption.

14 The typology was adopted in this paper for explanatory purposes.
} 
are not included in legal regulations; therefore, they can only arise spontaneously. It seems that the situation is similar as it pertains to the axiological foundations and constructional elements of the legal order. However, this article does not address how ,legal significance" is obtained through the constructional elements of law and legal order, thus influencing the content and interpretation of legal phenomena and the application of the law, nor does it cover the influence of the legal order's axiological basis on interpretation and application. This article will confine its subject matter to the spontaneous emergence of substantive norms and principles, rules, and guidelines for the interpretation of legal phenomena and the application of the law.

\section{Spontaneous Law-Making}

It is already known that law-making can be carried out formally, usually either on the basis of the normatively defined competences of state authorities or other entities, or spontaneously.

Traditionally, ,custom” is associated with the non-normative, non-formal formation of law, which I call the spontaneous formation of law. In addition, the definition of ,custom" is typically a manner of acting that is adopted under a given set of circumstances. This definition can be assigned to any norm, thus making it unclear what someone who is using it might mean. In reality, nobody actually uses the definition other than as a foundation; the result is the context in which the term ,custom" is generally used.

In the legal sciences, the meanings of the terms „custom” and „mores” are often used interchangeably. Their encyclopaedic definitions are clear on only one aspect, stating that ,custom” is the same as ,mores” [28:103-104]; however, ,custom” can be associated with several different phenomena [28:103-104].

Similarly, apart from the word's basic meaning, ,mores” may also refer to many different phenomena. ${ }^{15}$

Such a diversity of categorically different phenomena combined with mores and customs does not create a favourable environment for determining how these phenomena may be relevant to the content of the law or rather to the validity of the „unwritten” components of the sources of law.

An analysis of the content of legal regulations led to different conclusions. The meaning of the term ,mores" in the context of legal culture was subject to particularly far-reaching change. Mores originally had the power of ,unwritten law”; nowadays, the dominant position seems to be that the term refers to the socially popular habit of acting in a certain way in certain situations combined with the conviction that belonging to a given social circle (community) is concomitant with a particular way of acting. Such a position corresponds to the notions of habit that were proposed in the cultural sciences. It seems, however, that the concept of mores, as differentiated from individuals' other more random, personal behaviours, is used in relation

\footnotetext{
15 According to the same encyclopaedia, mores are a universally recognized, traditional form of behaviour adopted in a given social community. Ibid.
} 
to all the patterns of behaviour that are transmitted by tradition and observed by a group; that is, mores in the sense of the characteristic spirit of a culture (ethos).

Mores can be viewed as either conventionalised or unconventionalised. The criterion for distinguishing one from the other is whether a behaviour is undertaken because it leads to the realisation of some positively evaluated state of affairs (for instance, the mores that are associated with taking a spoon out of a glass during a meal serve to protect the health of the acting subject) as opposed to if a behaviour is undertaken only because something is 'done that way', for example, placing the plaintiff's and the defendant's signatures on the right-hand side of lawsuit paperwork [7: 11-89].

Due to the evolution of the meanings of the terms „,custom” and „mores”, the latter can be viewed as a social phenomenon in which case ,morality” may be placed partially in its sphere. At the same time, mores have lost their role in the moral sphere in favour of the principles of social coexistence; however, most proposed definitions of the principles of social coexistence include mores.

There is frequent overlap between the different meanings of „customs" and „mores" in the definitions that were previously considered appropriate for the common language as well as the cultural and legal sciences. The legal sciences take mores into account as a result of the role that customs play in regulations. Practically speaking, this inconsistency makes understanding both terms chaotic. A custom refers to the way that a particular norm is formed. These may be legal, moral, or religious mores or norms. In this approach, customary norms are those created by custom.

Similarly, the norms to which legal regulations refer are simply moral norms that are related to specific mores. Thus, mores may lead to the creation of law by custom in which case the legislator points it out and includes a specific reference in the regulation(s) [7: 11-89].

There are many known concepts for understanding a custom as a source of law. In contrast to historical school [19], classical concepts concerning the role of customs are distinguished by the fact that practice is a component of customary law. In historical school, practice was treated as a sign of the creation of a custom whereas classical concepts consider customary law to have been created on the basis of the so-called opinio iuris or opinio necessitatis and the practice of a specific type of conduct. In its two basic currents, classical concepts understand opinio iuris and opinio necessitatis differently. According to the theory of beliefs, opinion iuris is a common belief that applied norms are laws because their observance is a legal necessity [29: T1,80], [26: 12,13], [24:5]. A legal conviction is in fact tantamount to the conviction that the norm in question is a legally binding norm. A legal conviction may also arise from a belief that a given norm is reasonable as opposed to arising from another norm. According to the theory of will, the will of society is the source of all law. Conviction alone is not enough; acts of practice resulting from the so-called legal will (Rechtswille) are needed. However, conviction in the presence of will is neither the most important nor the only element of the creation of practice.

Within the framework of classical concepts, several essential requirements are placed on the practice in question. Such practice should be universal, permanent, even, reasonable, and consistent with good mores [29: T1,80], [26: 12,13], [24: 5]. 
The universality of practice is manifested in the fact that its acts are not isolated. It is not a matter of universality in society as a whole but rather within a group that is capable of creating a custom. The uniformity of practice involves considering the role of actions that could balance (destroy) a practice that goes in a certain direction, so that isolated practices are meaningless. The sustainability of a practice lies in repeating it for a long period of time. The reasonableness of the practice ensures that the rules of reasonableness are followed. There is also still compliance with good mores; notably, there is much more to say at present than there was at the time when the concepts of understanding and the role of customs were developed.

It is evident, then, that classical concepts assume the existence of customary law, which a state authority is obliged to take into account whenever such a law is present in community life. However, this concept was not adopted in Poland; instead, Poland abides by a concept that is based on the fact that a state authority (e.g., a court) decides, without any limitations, whether it will use an unwritten law, and even then, uses it only as a determinant of the legal situation of an entity [8:36]. Such a state of regulation imposes a difficult, high-responsibility task on state authorities and the courts in particular, thus giving rise to the danger of inventing a non-existent law or omitting one that was created by custom and has already been shaped. The events of 2016 to 2020 draw attention to such a possibility and urge the adoption of the principle of limited trust, or even lack of trust, in judges, officials, and politicians. This is all the more important because, in post-war Poland, the practice of taking customary law into account was not generally present in legal practice or in legal studies curricula, and the number of scientific papers in this area is low. This article asserts that these circumstances caused a legal void in the place where ,customary law” (created spontaneously) should function, triggering unjustified attempts during the interpretation process to extend the validity of normative acts to situations that are not regulated by it (and vice versa). Many Polish normative acts reference non-legal norms. Such references are not uncommon, but considerations of non-legal norms depend solely on the practically uncontrolled decision of the entity that is applying the law. As a state authority, such an entity can decide to (possibly) induct a norm that does not come from a normative act into the system of legal norms.

The difference with regard to considering common law, which, unlike a non-legal norm, is „objectively” present, only seems small, especially in the context of legal culture where these forms have been absent for a long time. This difference lies in customary law's readiness and acceptance as a law and a non-legal norm that can be used only as an interpretive determinant for an element of a legal situation. Customary law must be taken into account as law. In turn, customs and mores should be considered accordingly. Customary norms can only be determinants of the subjects or objects of the content of the law (in whole or in part) or the right or duty (or its fragment) of a participant in a legal situation. 
This issue was discussed in one work [14]. ${ }^{16}$ Its conclusions allow for the separation of two spheres in which law is spontaneously created. The first includes phenomena that result in the creation of substantive legal norms and principles of law, and the second encompasses phenomena that cause the principles, rules, and guidelines for the interpretation of legal phenomena and the application of the law to become legal norms that reflect the content of the law for a specific, factual situation.

\section{Phenomena Which Result in the Creation of Substantive Legal Norms}

Information about customs as a form of law creation can be found in all Polish textbooks that introduce jurisprudence [6: 33-48, 30: 21-25] however, the topic is described as an archaic form that is absent from the contemporary legal system. Meanwhile, ordered norms (sets of norms) can be seen in law-making from time to time, and sometimes their systems emerge in specific communities. These norms are either considered lawful or illegal (legal regulations). The norms that arise in certain communities are not considered spontaneous law although they are permanently observed.

The traditional conditions for granting the status of a law to non-legal norms that arise spontaneously, or rather, those that arise in the practice of their application, are as follows. In order for the result to be universal, durable, uniform, reasonable, and in alignment with good mores, which no longer seems fully valid, they require reconsideration in the context of the issue of rationality since it has appeared in place of ,reasonableness”. For example, in judicial decisions, whenever the court, when deciding on a matter, was aware of the need to reach for principles, rules, and guidelines for interpreting legal phenomena and applying the law, or even the rules of correct thinking, the praxeologically noticeable effects of certain actions or omissions were referred to as ,rationality”. However, it was a different rationality each time.

In this way, a circumstance emerged wherein the more different conditions were placed on legal practice in order to form the basis of the law, the more ,rationally" acceptable possibilities for understanding universality, permanence, uniformity, reasonableness, and compliance with good mores were found.

\footnotetext{
${ }^{16}$ R. Piszkos work „Determinants of the content and validity of directives on interpretation of the law in law and in legal practice". The paper was published in 2007 and, at that time, it was difficult to discern against the background that arose between 2015 and 2020 in connection with the debate as to its admissibility and the alteration of the constitutional system in the Republic of Poland. However, it was a work in which assumption (starting point) was a possibility for causing the collapse of the legal system in Poland due to the undetermined status of non-normative (unwritten) sources of law. Of course, this circumstance was unthinkable for the representatives of Polish legal doctrine at the time (and it is so even now). In addition, in the theory and philosophy of law, to an extent, it was not read with such an understanding [14].
} 


\section{Phenomena that Cause the Directives for the Interpretation of Legal Phenomena and the Application of the Law to Become Legal Norms That Implement the Content of the Law}

The principles, rules, and guidelines for the interpretation of legal phenomena and application have been the subject of studies that cover the issues of interpretative, inferential, reference, and conflict of laws directives. Considerations in this respect have been undertaken from various-or rather, practically all-possible points of view. In some cases, it was about the nature of legal reasoning [25] while, in others, it was about guidelines for legal practice [32]. Sometimes, it was about whether guidelines for legal practice should come from the observation of practice or whether they should be a consequence of a scientific study. However, the status of these directives, including the problem of their validity, was rarely discussed [14]. ${ }^{17}$

Meanwhile, substantive norms can be included in the law either through their incorporation in legal regulations or spontaneously. In virtually all legal systems, the principles, rules, and guidelines for the interpretation of legal phenomena and the application of the law are not included in legal regulations; therefore, they can only arise spontaneously [18]. ${ }^{18}$

The principles, rules, and guidelines for the interpretation of legal phenomena and the application of the law are, of course, instrumental. Determining which of them are binding requires taking into account not only the accuracy of their formulation but, above all, whether they are the subject of common practice combined with the conviction that they are binding as law. Perhaps the first step in indicating the basis for the application of the principles, rules, and guidelines for interpreting legal phenomena and applying law as legal norms is to establish a common means of understanding them in the science of law (validating role of legal doctrine, validating role of so called lawyer ideology). A similar issue concerning collecting empirical material was pursued by British authors in relation to the ideology of American lawyers [5: 277-335].

These studies draw attention to the impact of a lawyer's political orientation on the content of the law (by way of example the USA). Outside their scope, however, is the fact that the law can change unnoticed by the public through the use of certain directives of legal interpretation. Appropriately chosen interpretation directives can determine the content of the law to achieve specific policy objectives.

This article contains the concept of using such knowledge, in aspect in which political ideologies exemplify themselves in directives of legal interpretation.

\footnotetext{
17 This issue in Polish jurisprudence was of interest only to the author. It was not taken up by other authors and was not discussed in any other studies [14].

18 Introduction of terms: substantive norms (essential part) and instrumental norms - the component of usefulness of law (instrumental part) is not a typology-it is to be used only in the process of explaining the role of spontaneous creation of law.
} 


\section{Results}

A Polish legal system crisis pertaining to the Polish legal order's sources of law was inevitably concomitant with questioning the established practice of interpreting legal phenomena and applying the law because the sceptical interrogation of this same phenomena was previously present in judicial legal practice, and it can be assumed that this circumstance is what triggered the dispute involving the Constitutional Tribunal, the Supreme Court, and the common courts. Meanwhile, Polish jurisprudence has ignored the problems associated with the informal sources of law including issues related to the validity of directives on the interpretation of legal phenomena and the application of the law (a component of the usefulness of the law $^{19}$ ). It can be assumed that, in this way, realisations were made with regard to the aforementioned political consequences [1:329,330] of erroneous judicial practice and the limitations of jurisprudence as a subject in relation to the concept of sources of law. Such an effect could only have occurred in Poland when its legal system's standards approached those of the Western European legal systems, and it can be said that this happened in the 1970s. From that time, an increasing number of exceptions were made to the established practice of interpreting and applying legal phenomena, especially in courts, even in relation to individual cases where, for example, there were changes to sentencing guidelines [15]. ${ }^{20}$

The legal order has been reconstructed under communism since 1945, giving rise to a version that is deprived of the element of stabilisation with regard to the functioning of the state that is (usually) created by spontaneously arising law. As long as the direct, undemocratic administration of the affairs of state lasted, the legal order functioned correctly within a scope that met the expectations of the authorities of that time. When the democratic turn arrived, there was a lack of awareness of the essence of legal practice. There was also a lack of readiness to respect the established practice of law, including practice in the field of interpreting legal phenomena and applying the law (interpretation practice). Thus, for spontaneously arising legal practice (for example, so-called parliamentary mores, which are also known as constitutional mores, and rules for the interpretation of legal phenomena and the application of law) that attention turned out to be essential in allowing for the formulation of appropriate law content as well as correct usage.

In the order of established law, normative acts and the legal provisions contained therein are the means of conveying information about the law. In every legal system, however, the law is also created spontaneously regardless of whether it is provided for in the Constitution or in legal tuition. The principles, rules, and guidelines for the interpretation of legal phenomena and the application of the law are instrumental; if

\footnotetext{
19 In this work and for the purposes of the directive's deliberations, the author refers to the usefulness of law as the interpretation of legal phenomena and the application of law, without which it is impossible to determine the content of the law. This component is usually informal and is not regulated in normative acts.

20 More broadly [15].
} 
they are not subject to legal regulation, which is the case in Poland, they may-and, in reality, actually do-arise only spontaneously.

Legal science's omission of the problems that are associated with the principles, rules, and guidelines for the interpretation of legal phenomena and the application of the law leads to the absence of these in legal practice and as an element of the legal system. As a result, the discretionary power of entities that make decisions on behalf of the state extends to the possibility of using these principles, rules, or guidelines for legal interpretation and application, and the entity may choose (create) them for each individual case. That is the situation in the field of legal science have already caused disruptions in post-communist democracies. It is also possible for such distortions to appear in other countries' legal systems.

Therefore, a practical paradigm of verifying the directives of legal interpretation present in science or in legal practice as binding is needed. Such a paradigm may be based on reference to traditional conditions of law-making by custom. There are theoretically two traditional conditions of spontaneous arising of the law, which should be taken into account in order to develop a new concept. The conviction (the first) and the practice of a certain conduct (the second). Hypothetically, such a practice should be universal, permanent, even, reasonable, and it should correspond to good manners (i.e., a certain morality).

The matter to be considered is the way in which the conditions of spontaneous formation would be taken into account (legitimization of the interpretation of the law by way of custom). The further issues that need to be reviewed, are the completeness of these conditions in current political and social conditions, as well as the possible delegitimization of the conditions of formation of the law by way of custom.

The "initial" conditions are, as it is already known, conviction and practice: common, even, lasting, reasonable, in accordance with good manners. Most of these conditions can be maintained, but discourse is advisable in order to consider current theoretical-legal or linguistic concepts [9: 28-35].

Open Access This article is licensed under a Creative Commons Attribution 4.0 International License, which permits use, sharing, adaptation, distribution and reproduction in any medium or format, as long as you give appropriate credit to the original author(s) and the source, provide a link to the Creative Commons licence, and indicate if changes were made. The images or other third party material in this article are included in the article's Creative Commons licence, unless indicated otherwise in a credit line to the material. If material is not included in the article's Creative Commons licence and your intended use is not permitted by statutory regulation or exceeds the permitted use, you will need to obtain permission directly from the copyright holder. To view a copy of this licence, visit http://creativecommons.org/licen ses/by/4.0/.

\section{References}

1. Antoszewski, Andrzej, and Herbut, Ryszard. 2002. Leksykon politologii (Lexicon of Political Science). Warszawa: Wydawnictwo Alta 2, wyd.VI.

2. Bell, John. 2018. Sources of law. Cambridge Law Jornal 77 (1): 40-71. 
3. Bogucki, Olgierd. 2016. Model wyktadni funkcjonalnej w derywacyjnej koncepcji wykładni prawa (Model of Functional Interpretation in the Derivational Theory of Legal Interpretation). Szczecin: Polgres.

4. Bogucki, Olgierd. 2019. The derivational theory of legal interpretation in polish legal theory. International Journal for the Semiotics of Law. https://doi.org/10.1007/s11196-019-09628-1.

5. Bonica, Adam, S. Adam. Chilton, and Maya Sen. 2016. The political ideologies of American Lawyers. Journal of Legal Analysis 8 (2): 277-335. https://doi.org/10.1093/jla/lav011.

6. Chauvin, Tatiana, Stawecki, Tomasz and Winczorek, Piotr. 2017. Wstęp do prawoznawstwa. (Entry to jurisprudence). Warszawa: $\mathrm{CH}$ Beck.

7. Grad, Jan. 1993. Obyczaj a moralność: Próba metodologicznego uporzqdkowania badań dotychczasowych (Mores and morality, An attempt to methodologically organize the research conducted so far). Poznań: Wydawnictwo Naukowe UAM.

8. Grzybowski, Stefan. 1978. Prawo cywilne. Zarys części ogólnej (Civil law. Outline of the general part). Warszawa: PWN.

9. Kmita, Jerzy. 1997. Racjonalność decyzyjna, a badanie kultury (Decision-making rationality and culture research). In Rozumność i racjonalność (Reasonableness and rationality), ed. T. Buksinski. Wydawnictwo Naukowe UAM: Poznań.

10. Leszczyński, Leszek. 2020. Extra-legal values in judicial interpretation of law: a model reasoning and few examples. International Journal for the Semiotics of Law. https://doi.org/10.10007/s1119 6-020-99773-y.

11. Parliamentary inquiry. https://194.41.12.18/Sejm8.nsf/agent.xsp?symbol=RLISTAINT\&NrKad encji $=8 \& \mathrm{Nrl}=272$. Access 8 May 2020

12. Parliamentary inquiry. https://194.41.12.18/Sejm8.nsf/interpelacja.xsp?typ=INT\&nr=3193, access: 8.05.2020.

13. Parliamentary inquiryhttp://194.41.12.18/Sejm8.nsf/InterpelacjaTresc.xsp?key=61DE004B, access: 8.05.2020.

14. Piszko, Robert. 2007. Wyznaczniki treści $i$ obowiazywania dyrektyw wykładni prawa w prawoznawstwie $i$ w praktyce prawniczej (Determining the content and validity of directives on legal interpretation in law and legal practice). Szczecin: Wydawnictwo Naukowe US.

15. Piszko, Robert. 2015. Granice decyzji sqdowych (Borders of judicial decisions). Szczecin: PTE.

16. Piszko, Robert. 2019. Kryzys inkluzywnego rozwoju społeczeństwa obywatelskiego w Polsce (Crisis of inclusive development of civil society in Poland). Szczecin: Acta Iuris Stetinensis 2/2019: 95-108.

17. Piszko, Robert. 2020. Legitymizacja prawa, a spór wokół Trybunału Konstytucyjnego (Legitimization of the law and the dispute over the Constitutional Tribunal), Lublin: TEKA LUBLIN. Tom XII, $\mathrm{Nr} 1: 351-366$

18. Piszko, Robert. 2020. Spontaniczne powstawanie prawa i jego rola w porzqdku prawnym (Spontaneous formation of law and its role in the legal order), [w:] Studia na formalnymi i nieformalnymi źródtami prawa, 184-199. Towarzystwo Naukowe KUL Jana Pawła II: Lublin.

19. Puchta, Georg Friedrich. 1828. Das Gewohnheitsrecht. Palm: Erlangen in der Palmchen Verlagsbuchhandlung.

20. Rabault, Hugues. 1997. Granice wykładni sędziowskiej (Borders of judicial power). Warszawa: Wydawnictwo Naukowe Scholar.

21. Sen, Armartya. 2003. Rationality and Freedom. Cambridge, MA: Harvard University Press

22. Smith, Melanie. 2019. Staring into the abyss: A crisis of the rule of law in the EU. European Law Journal 25 (6): 561-576. https://doi.org/10.1111/eulj.12345.

23. Spyra, Tomasz. 2006. Granice wyktadni prawa (Boundaries of legal interpretation). Kraków: Zakamycze.

24. Staub-Pisko, Oskar. 1908. Kommentar zum allgemeinem deutschen Handelsgesetzbuch. Wien: Manzßche Hof-Verlags und Universitäts Buchhandlung.

25. Stelmach, Jerzy. 2006. Metody prawnicze (Judicial methods). Kraków: Zakamycze.

26. Studnicki, Franciszek. 1949. Działanie zwyczaju handlowego w zakresie zobowiazań z umowy (Functioning of commercial custom in terms of contractual obligations). Prace Komisji Prawniczej nr 4. Kraków: Polska Akademia Umiejętności

27. Kotarbiński, Tadeusz and various authors. 1970. Wielka Encyklopedia Powszechna (The Great Universal Encyclopedia).Warszawa: PWN.

28. Ulen, Shahan Thomas. 1999. Rational choise theory in law and economics. New York: Addison-Wesley. 
29. Winscheid, Bernhardt. 1862. Lehrbuch des Pandektenrechts. Verlagsbuchhandlung von J. Duddeus

30. Wronkowska, S.ławomira. 2005. Podstawowe pojęcia prawa i prawoznawstwa (Basic terms of law and jurisprudence). Poznań: Ars boni et aequi.

31. Wronkowska, S.ławomira, and Zygmunt Ziembiński. 1997. Zarys teorii prawa (Outline of legal theory). Poznań: Ars boni et aequi.

32. Zieliński, Maciej. 2008. Wykładnia prawa. Zasady. Reguły. Wskazówki (Legal Interpretation. Principles. Rules. Hints). Warszawa: LexisNexis.

33. Ziembiński, Zygmunt. 1978. Teoria prawa (Theory of law). Warszawa: PWN.

34. Ziembiński, Zygmunt. 1980. Problemy podstawowe prawoznawstwa (Fundamental problems of jurisprudence). Warszawa: PWN.

35. Zirk-Sadowski, Marek. 2012. Pojęcie, koncepcje i przebieg wykładni prawa administracyjnego (Concept, Conceptions and Course of the Interpretation of Administrative Law). In System prawa administracyjnegot Wyktadnia w prawie administracyjnym (System of Administrative law), vol. 4, ed. Leszek Leszczyński, 156-159. Warszawa: C.H. Beck.

36. Zirk-Sadowski, Marek. 2016. Problemy wyboru pomiędzy konkurującymi modelami wykładni prawa (Problems of choice between competing models of legal interpretation). Przeglad Prawa $i$ Administracji, nr 104 (CIV): 156-169.

Publisher's Note Springer Nature remains neutral with regard to jurisdictional claims in published maps and institutional affiliations. 